FACTA UNIVERSITATIS

Series: Physical Education and Sport Vol. 16, No 1, 2018, pp. 47 - 56

https://doi.org/10.22190/FUPES180411005B

Research article

\title{
EFFECTS OF PROGRAMMED FITNESS EXERCISE ON BODY COMPOSITION AMONG PRE-SCHOOL CHILDREN
}

\author{
UDC 796.012.1:611.7-053.4
}

\section{Predrag Bićanin ${ }^{1}$, Saša Milenković ${ }^{2}$, Dragan Radovanović ${ }^{2}$ Aco Gajević ${ }^{3}$, Jelena Ivanović ${ }^{1}$}

\author{
${ }^{1}$ Serbian Institute of Sport and Sports Medicine, Belgrade, Serbia \\ ${ }^{2}$ Faculty of Sport and Physical Education, University of Niš, Niš, Serbia \\ ${ }^{3}$ Faculty of Sport, University "Union Nikola Tesla", Belgrade, Serbia
}

\begin{abstract}
This research included a sample of 79 pre-school boys aged 6 and 7 with 40 of them in the experimental group and 39 in the control group. Their current state of body composition was studied, as well as their relations after a 6-month fitness treatment that the experimental group of participants was involved in, in order to analyze its effects. The experimental group had two classes per week, in addition to regular programmed activities as part of the children's sport school (three times per week), and as part of 48 of additional, six-month training lessons of exercising in sport (fitness) clubs. The following variables have been used to evaluate body composition with the application of bio-electric impedance In Body 230 such as: muscle mass, percentage of muscle mass, body fat mass, percentage of body fat mass, fat free mass, percentage of fat free mass. Although small to moderate effects were obtained by the double mixed ANOVA, the results show the experimental group's achievements as significantly higher than those of the control group. Furthermore, with individual eta coefficient findings in comparison with each group measurements, it is clear that the value of the obtained effects is different between groups to the benefit of the experimental group. Permanent implementation of the proposed programme could contribute to an improvement on the studied body composition variables which can result in the better health status of children in future.
\end{abstract}

Key words: fitness, body composition, pre-school children

Received April 11, 2018 / Accepted April 17, 2018

Corresponding author: Predrag Bićanin

Serbian Institute of Sport and Sports Medicine, St. Kneza Višeslava 72, 11000 Belgrade, Serbia

Phone: +381 113555 460• E-mail: bicanin.predrag@gmail.com 


\section{INTRODUCTION}

Child care, its health and normal physical growth is recognized as one of the most important tasks in upbringing with pre-school children. In contrast to other ages, pre-school children are still in the process of forming healthy habits that will further reflect their future life. That is why overweight children tend to take part in physical activities less (Planinsec \& Matejek, 2004). The World Health Organization (WHO, 2000) has recently been paying great attention to insufficient activities as a certain risk factor, equaling it with risk factors such as hypertension and obesity. For such reasons we can relate physical activity with the obesity percentage increase in children (Mendonza \& Anjos, 2004). Professional and scientific attention is more and more focused on children's obesity, bad body posture and insufficient physical activity, including an intensive need to monitor body composition and improvement of postural status with children (Burdyukova, Pustovalov, Oranskaya, Pertsov, \& Gurevich, 2012). We understand body composition (in anthropometry) as the composition of the human body represented by the size and combination of the existing measuring segments that it is composed of (Ugarković, 1996). The study of body composition should divide and measure body mass into basic components (Malina \& Bouchard, 1991, Malina, 2007), where theoretical frameworks have been used as the basis for the technology of development method for body composition measurements. These parameters have a significant social importance due to the direct relation of inactivity with many cardio-vascular diseases, hypertension and diabetes as the leading mortality causes among adults in developed countries, which was also confirmed in the previous research (Holbrook, Wingard, \& Barrett-Connor, 1990; Sjostrom, 1992). Body composition structure changes, which lead to obesity, are considered one of the most important public health problems of the modern age, and according to their estimation and frequency, this problem is the second cause that can be prevented successfully. Everyday participation in different forms of physical activity has a positive result on the growth and development of a young body (Ugarković, 1996; Ulić, 1997). Physical activity is especially important at the pre-school age. Contrary to the usual opinion that children sufficiently practice physical activities of middle to moderate intensity, the majority of recent studies showed that was not the case (Jago et al., 2011). Today, the famous experts for motor development recommend at least 60 minutes of programmed physical activity of middle to high intensity on a daily basis for school children (Tucker, 2008). Insufficient physical activity with pre-school and school children is an indicator of certain health problems that could become very serious if not remedied on time. In spite of this, it often happens that such problems are not spotted on time. Systematic monitoring and evaluation of the body composition, motor and postural status with children would provide timely evidence of many health problems - before any serious outcome.

Certain greater interest in this problem started with the more frequent occurrence of deformities among early school age children, and by a larger inclusion of children in institutional education and more intensive monitoring of their growth. Current research results, mostly based on establishing and defining morphological and postural status, showed that pre-school and school institutions had an increasing number of fat children with postural damages and anatomic changes of the foot (Ogden, Flegal, Carroll, \& Johnson, 2002; Božić-Krstić, Rakić, \& Pavlica, 2003; Trajković \& Nikolić, 2008; Bala, Jakšić, \& Katić, 2009; Martinović, Pelemiš, Branković, \& Mitrović, 2012; Ogden, Carroll, Kit, \& Flegal, 2014). The lack of references to these problems certainly made it more difficult to elaborate on the mentioned phenomena, which are the subject of this 
research. One of the most important reasons for the insufficient number of studies dealing with this topic includes lack of attention with children of this age, which consequently leads to a lack of adequate and precise anthropometric measurements and execution of programmed physical exercising. Children of this age are naturally active and impatient, so these achievements are boring to them which causes great difficulty for researchers. It is important to emphasize the second reason that contributed to a more difficult comparative analysis; the fact that in almost all former research, the control group of participants was not under the influence of physical activities. This was not the case in this research. Control and experimental groups were both involved in organized programmed physical exercises in the framework of so-called sport schools whose main objective is the complete development of the total morphological and functional potentials of each child, and advancement in each of the aspects. We must not forget the fact that different apparatuses we used in to measure postural status and body composition in relation with this research.

The main goal of this research is to determine the effect of a six-month programmed fitness exercise on body composition among pre-school children.

\section{METHODS}

\section{Participants}

The sample consisted of 79 children 6 to 7 years of age, with 40 participants in the experimental group. They were, in addition to their regular activities as a part of the children's school of sport (3 times per week), included in 48 additional training classes during a six-month period in sport (fitness) clubs. The control group had 39 participants who had their regular programme activities as part of the children's school of sport (3 times per week) and did not participate in any additional exercises out of the institutional programme.

\section{Measuring instruments}

The body composition of the participants was obtained on the basis of data collected by measuring the body height and composition obtained by application of the method of multicultural bio-electric impedance - BIA (In Body 230, Seoul, Korea). The validity and reliability of this instrument was evaluated in previous research (Bedogni et al., 2013; Karelis, Chamberland, Leheudre, \& Duval, 2013)

\section{The sample of variables}

For body structure estimation, the following variables were used:

- Muscle Mass - MM, in kg

- Percentage of Muscle Mass - PMM, in \%

- Body Fat Mass - BFM, in kg

- Percentage of Body Fat Mass - PBFM, in \%

- Fat Free Mass - FFM, in kg

- Percentage of Fat Free Mass - PFFM, in \% 


\section{Experimental programme}

Participants of the experimental group, in addition to 3 classes of regular programmed activities as part of the children's sport school, realized 2 additional classes per week for a total of 48 additional training classes over a six-month period in sport (fitness) clubs in Belgrade. The training class structure for the realization of the experimental children fitness programme with the experimental group of participants contained four parts:

The introductory part of the class (3-5 minutes) was aimed to warm up the body and to introduce them to organized work for task realization in the main part of the class. The simple forms of natural movement were applied, or biotic motor knowledge (walking and fast walking, running, jumping, etc.) with already formed the motor stereotype to enable a dynamic regime of work for the whole body.

The preparatory part of the class (8-10 minutes) was aimed at engaging the entire muscle system, to prepare muscles, particularly tendons and ligaments for full engagement of the body for task realization in the main part of the class.

The main part of the class contained motor exercises (basic elements of basic preparation with elements of children's fitness as well as improvements of postural status), and it lasted for 20-25 minutes.

The final part of the class (3-5 minutes) was aimed to encourage reconciliation processes by a gradual calming of all functions of the body and emotions of the participants through weaker dynamic and intensity (e.g. relaxing jumping, loosening and stretching of the shoulders and pelvis).

\section{Data processing}

In regard to statistical methods, beside a descriptive statistic model, here we used a single variant and Multivariate statistical analysis of the General Linear Model. According to Cohen (1988) the evaluation of differences was done on the basis of effects size (VE). For the evaluation effects and interactions of the main factors with the ANOVA, here we applied the partial coefficient eta $(\mathrm{p} \eta 2)$ where the effect was considered as: small for $(\mathrm{p} \eta 2)=0.01$, moderate for $(\mathrm{p} \eta 2)=0.006$ and large for $(\mathrm{p} \eta 2)=$ 0.15. All statistic methods were processed in the software SPSS package for Windows, Release 20.0 (Copyright (C SPSS Inc., 1989-2011).

\section{RESULTS}

The multivariate statistical analysis determined, for the studied sub-sample of preschool children of the experimental group, that a general and statistically significant difference existed between the measurements of all the examined indexes for body composition estimation at the level of Wilks`Lambda 0.829, F=2.296, p=0.045.

Descriptive statistic results and partial differences between initial and final measurements with indexes for body composition estimation with the experimental group are illustrated in Table 1. 
Table 1 Differences of indexes for the body composition estimation of the experimental group

\begin{tabular}{lccccccc}
\hline & $\begin{array}{c}\text { Initially } \\
\text { (mean value) }\end{array}$ & $\begin{array}{c}\text { Finally } \\
\text { (mean value) }\end{array}$ & $\begin{array}{c}\text { Absolute } \\
\text { differences }\end{array}$ & $\begin{array}{c}\text { Relative } \\
\text { differences }\end{array}$ & $\begin{array}{c}\text { F } \\
\text { value }\end{array}$ & Significance & $\begin{array}{c}\text { eta } \\
\left(\mathrm{p}^{2}\right)\end{array}$ \\
\hline MM (kg) & 8.61 & 9.87 & -1.27 & -12.82 & 6.734 & 0.011 & 0.086 \\
BFM (kg) & 4.70 & 5.17 & -0.48 & -9.22 & 0.486 & 0.488 & 0.006 \\
FFM (kg) & 18.21 & 20.24 & -2.03 & -10.02 & 6.162 & 0.015 & 0.077 \\
PBFM (\%) & 19.68 & 19.45 & 0.22 & 1.15 & 0.028 & 0.867 & 0.000 \\
PMM (\%) & 38.09 & 39.22 & -1.13 & -2.88 & 2.581 & 0.113 & 0.035 \\
PFFM (\%) & 80.39 & 80.49 & -0.10 & -0.12 & 0.005 & 0.942 & 0.000 \\
\hline
\end{tabular}

MM - Muscle mass, BFM - Body Fat Mass, FFM - Fat Free Mass, PBFM - Percentage of the Body Fat

Mass, PMM - Percentage of Muscle Mass, PFFM - Percentage of Fat Free Mass.

The multivariate statistical analysis found that within the observed sub-sample of preschool children of the control group a general statistically significant difference between measurements existed for all the examined indexes for the evaluation of the body composition at the level of Wilks`Lambda 0.732, $\mathrm{F}=4.037, \mathrm{p}=0.002$; while at the partial level within observed sub-samples, one was not established. The results of descriptive statistics and partial differences between the initial and final measurements with indexes for the estimation of postural composition with the control group are illustrated in Table 2.

Table 2 Differences of indexes for evaluation of the body composition of the control group

\begin{tabular}{lccccccc}
\hline & $\begin{array}{c}\text { Initially } \\
\text { (mean value) }\end{array}$ & $\begin{array}{c}\text { Finally } \\
\text { (mean value) }\end{array}$ & $\begin{array}{c}\text { Absolute } \\
\text { differences }\end{array}$ & $\begin{array}{c}\text { Relative } \\
\text { differences }\end{array}$ & $\begin{array}{c}\text { F } \\
\text { value }\end{array}$ & Significance & $\begin{array}{c}\text { eta } \\
\left(\mathrm{p} \eta^{2}\right)\end{array}$ \\
\hline MM (kg) & 7.80 & 8.70 & -0.90 & -10.38 & 3.550 & 0.064 & 0.048 \\
BFM (kg) & 4.13 & 4.51 & -0.38 & -8.35 & 0.309 & 0.580 & 0.004 \\
FFM (kg) & 16.63 & 18.18 & -1.55 & -8.54 & 3.861 & 0.053 & 0.052 \\
PBFM (\%) & 19.03 & 18.84 & 0.19 & 0.99 & 0.018 & 0.894 & 0.000 \\
PMM (\%) & 38.59 & 38.61 & -0.02 & -0.05 & 0.253 & 0.617 & 0.004 \\
PFFM (\%) & 82.31 & 81.23 & 1.08 & 1.33 & 0.177 & 0.675 & 0.002 \\
\hline
\end{tabular}

MM - Muscle mass, BFM - Body Fat Mass, FFM - Fat Free Mass, PBFM - Percentage of the Body Fat Mass, PMM - Percentage of Muscle Mass, PFFM - Percentage of Fat Free Mass.

Statistical findings of the double mixed ANOVA, the value of the effects and the direction of the test effects are illustrated in Table 3 for indexes for the evaluation of body composition. Generally, the findings differentiate and for the variables MM, FFM, PMM and PFFM small effects of the programme were noted, where the experimental group had an improvement in the final measurement. On the other hand, for the BFM variable effects were obtained of the both factors, and for the PBFM effects of one factor were obtained, but a lack of Test $\mathrm{x}$ Group interaction has not confirmed potential differences in the programme effects on the two groups. 
Table 3 Effects of programmed fitness exercise on the indexes for the evaluation of body composition

\begin{tabular}{|c|c|c|c|c|c|c|}
\hline Variables & Effects & $\mathrm{F}$ & $\mathrm{p}$ & $\eta_{p}^{2}$ & $\mathrm{VE}$ & Effect direction \\
\hline \multirow{3}{*}{ MM (kg) } & group & 8.426 & 0.004 & 0.056 & moderate & $\mathrm{E}>\mathrm{C}$ \\
\hline & measurement & 10.055 & 0.002 & 0.066 & moderate & Init $<$ Fin \\
\hline & group $\times$ measurement & 0.281 & 0.597 & 0.002 & small & Init: $\mathrm{E}>\mathrm{C}$ Fin: $\mathrm{E}>\mathrm{C}$ \\
\hline \multirow{3}{*}{ BFM (kg) } & group & 1.539 & 0.217 & 0.011 & moderate & $\mathrm{E}>\mathrm{C}$ \\
\hline & measurement & 0.721 & 0.397 & 0.005 & small & Init $<$ Fin \\
\hline & group $\times$ measurement & 0.007 & 0.934 & 0.000 & / & Init: $E>C$ Fin: $E>C$ \\
\hline \multirow{3}{*}{ FFM (kg) } & group & 8.691 & 0.004 & 0.057 & moderate & $\mathrm{E}>\mathrm{C}$ \\
\hline & measurement & 10.402 & 0.002 & 0.068 & moderate & Init $<$ Fin \\
\hline & group $\times$ measurement & 0.227 & 0.635 & 0.002 & small & Init: $\mathrm{E}>\mathrm{C}$ Fin: $\mathrm{E}>\mathrm{C}$ \\
\hline \multirow{3}{*}{$\operatorname{PBFM}(\%)$} & group & 0.438 & 0.509 & 0.003 & small & $\mathrm{E}>\mathrm{C}$ \\
\hline & measurement & 0.045 & 0.832 & 0.000 & / & Init $>$ Fin \\
\hline & group $\times$ measurement & 0.004 & 0.982 & 0.000 & / & Init: $\mathrm{E}>\mathrm{C}$ Fin: $\mathrm{E}>\mathrm{C}$ \\
\hline \multirow{3}{*}{ PMM (\%) } & group & 0.014 & 0.908 & 0.000 & I & $\mathrm{E} \approx \mathrm{C}$ \\
\hline & measurement & 1.507 & 0.230 & 0.051 & small & Init $<$ Fin \\
\hline & group $\times$ measurement & 0.812 & 0.375 & 0.028 & small & Init: $\mathrm{E}<\mathrm{C}$ Fin: $\mathrm{E}>\mathrm{C}$ \\
\hline \multirow{3}{*}{ PFFM (\%) } & group & 0.924 & 0.344 & 0.031 & small & $\mathrm{E}<\mathrm{C}$ \\
\hline & measurement & 0.252 & 0.619 & 0.009 & small & Init $<$ Fin \\
\hline & group $\times$ measurement & 0.501 & 0.485 & 0.017 & small & Init: $\mathrm{E}<\mathrm{C}$ Fin: $\mathrm{E}<\mathrm{C}$ \\
\hline
\end{tabular}

MM - Muscle mass, BFM - Body Fat Mass, FFM - Fat Free Mass, PBFM - Percentage of the Body Fat Mass, PMM - Percentage of Muscle Mass, PFFM - Percentage of Fat Free Mass, E - experimental group,

$\mathrm{C}$ - control group, Init - initial measurements, Fin - final measurements.

\section{DISCUSSION}

The research results regarding the differences between measurements with indexes of body composition with participants in the experimental group established statistically significant differences in the observed indexes of the muscle mass and fat free mass component (Table 1). Contrary to the experimental group, the research results review difference between measurements with indexes of body composition among the participants of the control group have not established statistically significant differences in the observed indexes (Table 3). Regardless of the lack of the statistically significant differences with other monitored indexes, the fact that the experimental children fitness programme involving children in the experimental group, if we compare initial and final measurements, certain changes occurred particularly with monitored indexes the percentage of muscle mass and percentage of fat free mass component. These changes are even more visible in Figure 1 which illustrated the results and differences between measurements with both monitored groups. It is obvious that the experimental group advanced more in comparison with the control group with all the monitored indexes for the evaluation of body composition (Figure 1). 


\section{$\%$ differences between measurements}

$$
\square \text { control group } \square \text { experimental group }
$$

Percentage of Fat Free Mass

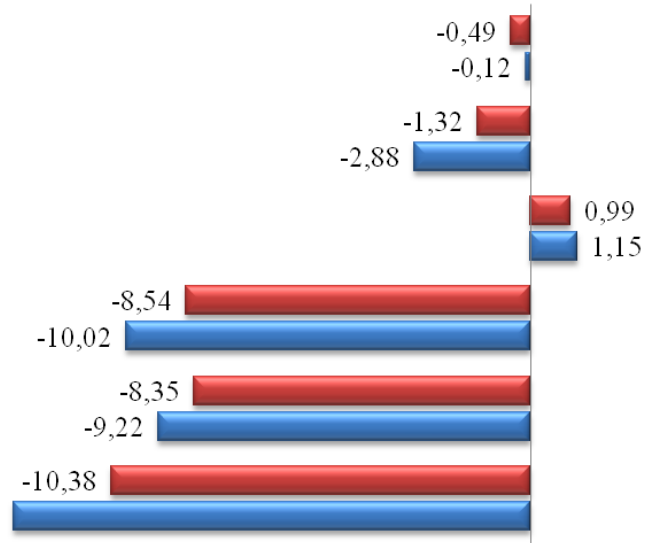

Fig. 1 Differences in the percentage of monitored parameters for the evaluation of body composition between measurements with both monitored groups

The values of the partial coefficient eta (Table 3) speak in favour of this. Although small to moderate effects are obtained by evidence of a double mixed ANOVA, the results show that the experimental group, which had, in addition to 3 regular lessons of programme activities as part of the children's sport school, 2 more lessons per week within experimental children fitness programme, and achieved statistically significantly higher advancement in the monitored indexes than the control group which only had 3 regular programme activities within children sport school. When we compare single findings of the eta coefficient in relation with each group between measurements (Tables $1,2)$ it is obvious that the value of obtained effects is different between groups, in favour to the experimental group.

It is clear that the growth and development in combination with additional physical exercise produced certain changes in body composition since the control group had also been exposed to physical exercise treatment. The tendency of early involvement of children in programmed physical activities unavoidably leads to modification in the sense of more utilitarian effects on the youngest in the broadest sense (Tucker, 2008), which is also confirmed by the results of this research.

These facts are supported by recent research that also included an additional programme of physical activities where, compared to the group that had no physical exercise programmes, the results showed a reduction of body fat mass (Adamo et al., 2014; Pelemiš, 2016). In order to prevent obesity, many authors propose an increase in physical activities, starting at the earliest age (Graf et al., 2004; Planinsec and Matejek, 2004). The examination of differences in physical activity on a sample of pre-school children established significant differences with both genders in relation to moderate to strong exercise during weekends and total weekly activities among not fat and fat, and among excessively fat and fat children (Planinsec \& Matejek, 2004); children who 
actively spent their time exercising had a positive correlation with total development of motor skills and fat children had weaker results in all testings of motor skills (Graf et al., 2004); boys and girls who participated in physical activity more at the age of 5 years had less Body Fat Mass then children in the age of 8 and 11 years who had lower values of physical activities (Janz et al., 2009). Also, programmed activities 30 minutes long performed on a daily basis with professors of physical education affected anthropometric dimensions of pre-school children, such as: body height, body mass, legs length, arm's length, foot length, head volume, average head volume, average chest volume, shoulders width, heaps width, pelvic width, palm with fingers length, wrist diameter, forearm volume, back skinfold, arm skinfold, and abdominal skinfold (Markov \& MesarošŽivkov, 2010). Besides, the research results of Lepeš, Halaši, Mandarić, \& Tanović (2014) obtained from a sample of 125 seven-year-old children showed that the variable predictor system for the evaluation of body composition (total quantity of grease, water and muscle) is statistically significantly connected with criteria defined as a general motor factor with $39 \%$ of common variability with boys and $34 \%$ with girls. The standardised regression coefficient illustrates for boys and for girls that the total value of fat in the body and body weight negatively affects general motor skills; and body height with girls has a positive effect. Unfortunately, as it is stated above, the available literature offers too little information how organized physical activity can influence the health conditions of pre-school children. This statement is supported by many authors. We will quote here the conclusions in the work of Venetsanou, Kambas, \& Giannakidou (2015) who examined how organized physical activity can support the promotion of health with pre-school children and particularly health indicators such as obesity, skeleton health, cardio-metabolic health, motor skills development, cognitive development, and psychosocial health. The authors quote that the majority of studies $(n=13)$ consider that organised physical activity effects children`s level of motor skills, while there is a modest number of those who examined the rest of the health indicators - obesity $(n=4)$, skeleton health $(n=2)$, cardio-metabolic health $(n=0)$, cognitive development $(n=2)$, and psychosocial health status $(n=4)$. They believe that the question about the kind and intensity or frequency of physical activity necessary to improve children`s health is insufficiently examined. The conclusion of this study is that further research on the relation between organized physical activity and health in pre-school age is needed in order to bring clearer conclusions that will enable the development of efficient programmes of physical activities for the promotion of children`s health.

\section{CONCLUSION}

Regarding the primary objection of this research, i.e. by implementation of the experimental method to establish whether the particularly programmed six month fitness exercise in the regular conditions of the sport school work resulted in significant changes in the body composition of pre-school children; and based on the results obtained by the research, it is possible to conclude that a six-month long experimental fitness programme led to positive effects in the body composition of the experimental group. Although small to moderate effects obtained in the findings of double mixed ANOVA showed that the experimental group, which had three classes of regular programme activities in the children sport school, and additional two classes per week of the experimental children 
fitness programme, have achieved statistically significant higher advancement in the monitored indexes than the control group which had only three regular programme activities in the children sport school.

Also, in relation to the individual findings of the eta coefficient in comparison with each group separately between measures, the value of the obtained effects differentiates between the groups in favour of the experimental group.

\section{LIMITATION OF STUDY AND FUTURE RESEARCH}

For generalization of data obtained in the general population, it is necessary to carry out extensive research as soon as possible. Though in the available literature an extremely small number of research works on effects of corrective programmes on the body composition in pre-school childrenexists, the results of this study should serve the function of the most informative indicators that will enrich the technological process of managing, monitoring, control improving, and optimizing the programmed exercise in the given population.

\section{REFERENCES}

Adamo, K.B., Barrowman, N., Naylor, P.J., Yaya, S., Harvey, A., Grattan, K.P., \& Goldfield, G.S. (2014). Activity begins in childhood (ABC) - Inspiring healthy active behaviour in preschoolers: study protocol for a cluster randomized controlled trial. Trials, 2, 305-315.

Bala, G., Jakšić, D., \& Katić, R. (2009). Trend of relations between morphological and motor abilities in preschool children. Collegium Antropologicum, 33 (2), 373-385.

Bedogni, G., Agosti, F., De Col, A., Marazzi, N., Tagliaferri, A., \& Sartorio, A. (2013). Comparison of dualenergy X-ray absorptiometry, air displacement plethysmography and bioelectrical impedance analysis for the assessment of body composition in morbidly obese women. European Journal of Clinical Nutrition, 67 (11), 1129-1132.

Božić-Krstić, V., Rakić, R., \& Pavlica, R. (2003). Body mass and height of preschool and younger school children in Novi Sad. Journal of the Anthropological Society of Serbia, 38, 91-101.

Burdyukova, E.V., Pustovalov, D.A., Oranskaya, A.N., Pertsov, S.S., \& Gurevich, G.K. (2012). Mechanisms of Maladaptation to Physical Exercise in Moscow Schoolchildren. Bulletin of Experimental Biology and Medicine, 153 (4), 428-430.

Cohen J. (1988). Statistical power analysis for the behavioral sciences. New York: Routledge Academic.

Graf, C., Koch, B., Kretschmann-Kandel, E., Falkowski, G., Christ, H., Coburger, S., Lehmacher, W, Bjarnason-Wehrens, B., Platen, P., Tokarski, W., Predel, H. G., \& Dordel, S. (2004). Correlation between BMI, leisure habits and motor abilities in childhood (CHILT-project). International Journal of Obesity and Related Metabolic Disorders, 28(1), 22-26.

Holbrook, T.L., Wingard, D.L., \& Barrett-Connor, E. (1990). Sex-specific vs unisex body mass indices as predictors of non-insulin dependent diabetes mellitus in older adults. International Journal of Obesity, 14 (9), 803-807.

Jago, R., Davison, K. K., Brockman, R., Page, A.S., Thompson, J.L., \& Fox, K.R. (2011). Parenting styles, parenting practices, and physical activity in 10 to 11-year olds. Preventive Medicine, 52 (1), 44-47.

Janz, F., Kwon, S., Letuchy, M., Eichenberger Gilmore, M., Burns, L., Torner, C., Willing, C., \& Levy, M. (2009). Sustained effect of early physical activity on body fat mass in older children. American Journal Preventive Medicine, 37, 35-40.

Karelis, A.D., Chamberland, G., Leheudre, M.A., \& Duval, C. (2013). Validation of a portable bioelectrical impedance analyzer for the assessment of body composition. Applied Physiology, Nutrition, and Metabolism, 38 (1), 27-32

Lepeš, J., Halaši, S., Mandarić, S., \& Tanović, N. (2014). Relation between body composition and motor abilities of children up to 7 years of age. International Journal of Morphology, 32 (4), 1179-1183. 
Malina, R.M., \& Bouchard, C. (1991). Growth, Maturation and Physical Activity. Champaign, IL: Human Kinetics.

Malina, R.M. (2007). Body composition in athletes: Assessment and estimated fatness. Clinics in Sports Medicine, 26, 37-68.

Markov, Z., \& Mesaroš-Živkov, A. (2010). The effects of the application of programmed physical exercise on anthropometric dimensions in preschool children. Pedagoška stvarnost, 56(7-8), 630-648.

Martinović, D., Pelemiš, V., Branković, D., \& Mitrović, N. (2012). Quantitative differences in anthropometric characteristics of pre-school boys and girls. Journal Plus Educatia, 8 (2), 109-118.

Mendonza, C.P., \& Anjos, L.A. (2004). Dietary and physical activity factors as determinants of the increase in overweight/obesity in Brazil. Cadernos de Saúde Pública, 20 (3), 698-709.

Ogden, C., Flegal, K., Carroll, M., \& Johnson, C. (2002). Prevalence and trends in overweight among U.S. children and adolescents, 1999-2002. Journal of the American Medical Association, 288, 1728-1732.

Ogden, L.C., Carroll, D.M., Kit, K.B., \& Flegal, M.K. (2014). Prevalence of childhood and adult obesity in the United States, 2011-2012. The Journal of the American Medical Association, 311(8), 806-814.

Pelemiš, V. (2016). The impact of additional program of physical exercise on morphological and motor status of preschool children. Ph. D Thesis. Novi Sad: University of Novi Sad, Faculty of Sport and Physical Education.

Planinsec, J., \& Matejek, C. (2004). Differences in physical activity between non-overweight, overweight and obese children. Collegium Antropologicum, 28 (2), 747-754.

Sjostrom, L.V. (1992). Morbidity of severely obese subjects. The American Journal Of Clinical Nutrition, 55 (2), 508-515

Trajković, S., \& Nikolić, M. (2008). Comparative analysis of anthropometric measures and postural disorders of school children of generation in 1987 and 2002. Journal of the Anthropological Society of Serbia, 43(1), 386-391.

Tucker, P. (2008). The physical activity levels of preschool-aged children: A systematic review. Early Childhood Research Ouarterly, 23, 547-558.

Ugarković, D. (1996). Biology of human development with the basics of sports medicine. Belgrade: Faculty of Physical Culture.

Ulić, D. (1997). Mogućnost otklanjanja lošeg držanja tela sredstvima fizičkog vaspitanja (Possibility of elimination of poor posture by physical education). Fizička kultura, 46(1), 36-37. In Serbian

Venetsanou, F., Kambas, A., \& Giannakidou, D. (2015). Organized physical activity and health in preschool age: A Review. The European Journal of Public Health, 23(3), 200-207.

World Health Organization-WHO (2000). Obesity: Preventing and managing the global epidemic. Technical Report Series, 894. Geneva: WHO.

\section{EFEKTI PROGRAMIRANOG FITNES VEŽBANJA NA TELESNU KOMPOZICIJU DECE PREDŠKOLSKOG UZRASTA}

U ovom istraživanju je na uzorku od 79 predškolaca uzrasta 6 i 7 godina muškog pola, od čega 40 ispitanika eksperimentalne grupe i 39 ispitanika kontrolne grupe ispitano trenutno stanje telesne kompozicije, te njihov odnos posle primenjenog šestomesečnog tretmana fitnes vežbanja nad eksperimentalnom grupom ispitanika u cilju istraživanja efekata istog. Eksperimentalna grupa je pored redovnih programskih aktivnosti u okviru dečije škole sporta (tri puta nedeljno) bila uključena kroz još dva časa nedeljno, u okviru 48 dodatnih trenažnih časova vežbanja u trajanju od šest meseci, u sportskim (fitnes) klubovima. Za procenu telesnog sastava korišćene su sledeće varijable dobijene primenom Bioelektrične impedanse "In Body 230": Mišićna masa, Procenat mišićne mase, Količina masti u telu, Procenat telesnih masti, Bezmasna komponenta, Procenat bezmasne komponente. Iako mali do umereni efekti dobijeni nalazima dvostruke mešovite ANOVAe, rezultati pokazuju da je eksperimentalna grupa, ostvarila statistički značajno veći napredak od kontrolne grupe. Takođe, $i$ u odnosu na pojedinačne nalaze koeficijenta eta u odnosu na svaku grupu ponaosob između merenja uočljivo je da se veličina dobijenih efekata razlikuje između grupa u korist eksperimentalne. Stalna primena predloženog programa mogla bi doprineti poboljšanju ispitivanih varijabli vezanih za telesni sastav, što može rezultirati boljim zdravstvenim statusom dece u kasnijem zivotnom dobu.

Ključne reči: fitnes, telesna kompozicija, predškolski uzrast 